\title{
Antibiotic treatment of abscesses of the central nervous system
}

\author{
JOHN DE LOUVOIS, PETER GORTVAI, ROSALINDE HURLEY
}

British Medical fournal, 1977, 2, 985-987

\begin{abstract}
Summary
Samples of intracranial pus and serum from 32 patients were assayed to determine the concentrations reached in them of penicillin, ampicillin, cloxacillin, cephaloridine, gentamicin, chloramphenicol, fusidic acid, and lincomycin. Metronidazole had not been given. Penicillin penetrated abscesses reasonably well, but other betalactam antibiotics did not. The penetration of chloramphenicol was erratic. Aminoglycosides penetrated poorly, but lincomycin and fusidic acid penetrated well. Assay of sulphonamides and co-trimoxazole in pus was unreliable.
\end{abstract}

These studies indicate that treatment of abscesses of the central nervous system should be considered according to the site and the likely antecedent cause. Abscesses of sinusitic origin, usually in the frontal lobe, yield penicillin-sensitive streptococci. Penicillin is the drug of choice. Abscesses of otitic origin, usually in the temporal lobe, yield a mixed flora, often including anaerobic bacteria. Multiple antibiotic therapy is indicated. Abscesses of metastatic or cryptogenic origin yield streptococci or mixed cultures, and multiple therapy is appropriate while awaiting the bacteriological results. Spinal and post-traumatic abscesses yield Staphylococcus aureus, and fusidic acid is the drug of choice.

\section{Introduction}

The penetration of antimicrobial drugs to infected sites in the central nervous system (CNS) is complicated by the peculiar impermeability of the vasculature, known as the blood-brain barrier. The demonstration that the blood-brain and the blood-cerebrospinal fluid (CSF) barriers are different' has meant that the considerable amount of information on antibiotic levels in $\mathrm{CSF}^{2}$ cannot be used to calculate drug levels in brain tissue or intracranial pus. Although the effectiveness of chemotherapy depends on penetration of the drug to the infected site, there have been only a few reports on antibiotic concentrations in human brain tissue ${ }^{3}$ ' and only one on antibiotic concentrations in intracranial pus."

This investigation was undertaken to determine which of the antimicrobial drugs used by neurosurgeons at six centres in England could penetrate intracranial abscesses and, together with relevant clinical information collected in the course of a multicentre study, ${ }^{6}$ to determine which antibiotic regimens are most appropriate for treating intracranial abscesses.

Queen Charlotte's Maternity Hospital, London

JOHN DE LOUVOIS, PHD, principal microbiologist

ROSALINDE HURLEY, MD, FRCPATH, professor of microbiology

Regional Centre for Neurosurgery, Oldchurch Hospital, Romford

PETER GORTVAI, MD, FRCS, consultant neurosurgeon

\section{Patients and methods}

Samples of pus and blood were collected from 32 patients with brain abscesses or subdural or extradural empyemata. Specimens were transported to the examining laboratory by express road or rail services." " Serum samples were separated immediately on arrival and, together with the pus samples, were assayed without further delay. Horse serum standards for the anticipated assay were prepared as soon as collection of the samples was notified. They were stored at $4^{\circ} \mathrm{C}$, the temperature at which samples were transported, until the assay was performed. Mucoid samples of pus were liquefied by pancreatin, ' an accurate volumetric measurement of the pus being made, after liquefaction, by the method of subtraction. When pancreatin treatment of pus was necessary the antibiotic standards were treated similarly. The assay of one antibiotic in the presence of another was performed by means of drug-resistant indicator organisms, chemical inactivation, or differential diffusion. A flood plate assay system was used for all antibiotics tested. The medium, $\mathrm{pH}$, and indicator organisms used varied according to the agent being assayed. '

\section{Results}

No attempt was made to influence neurosurgeons in their choice of antimicrobial drugs and each adopted the regimen of treatment thought to be appropriate. In addition to the -lactam antibiotics, chloramphenicol, co-trimoxazole, sulphonamides, aminoglycosides, fusidic acid, and lincomycin were used. Metronidazole was not used.

Altogether 160 assays were carried out on pus and serum samples from 32 patients with suppurative lesions of the central nervous system. Twenty-three patients received penicillin and the drug was detectable in the pus or serum, or both, from 17 of these patients (table I). The remaining six patients, who were receiving 8-24 megaunits of penicillin a day, had no detectable drug in their serum or pus; in four cases this may have been due to $\$$-lactamase produced by the infecting micro-organisms. Irrespective of dose there was wide variation in the concentrations of penicillin both in serum and pus.

TABLE I-Concentrations of penicillin in serum and intracranial pus of 17 patients

\begin{tabular}{|c|c|c|c|}
\hline $\begin{array}{l}\text { Reported dose } \\
(\mathrm{MU} 24 \mathrm{~h})\end{array}$ & Route & $\begin{array}{l}\text { Serum } \\
(\mathrm{mg} / 1)\end{array}$ & $\underset{(\mathrm{mg} / \mathrm{l})}{\mathrm{Pus}}$ \\
\hline $\begin{array}{r}1 \cdot 6 \\
4 \cdot 0 \\
4 \cdot 0 \\
4 \cdot 0 \\
4 \cdot 0 \\
4 \cdot 0 \\
6 \cdot 0 \\
6 \cdot 0 \\
6 \cdot 4 \\
6 \cdot 4 \\
8 \cdot 0 \\
8 \cdot 0 \\
12 \cdot 0 \\
12.0 \\
12 \cdot 0 \\
12 \cdot 0 \\
12 \cdot 0 \\
12.0 \\
24 \cdot 0 \\
24 \cdot 0 \\
24 \cdot 0 \\
24 \cdot 0 \\
24 \cdot 0 \\
40 \cdot 0 \\
\mathrm{NK} \\
\mathrm{NK} \\
\mathrm{NK} \\
\mathrm{NK} \\
\mathrm{NK}\end{array}$ & $\begin{array}{c}\text { Oral } \\
\mathrm{NK} \\
\mathrm{NK} \\
\mathrm{NK} \\
\mathrm{NK} \\
\text { Intravenous } \\
\text { Intramuscular } \\
\text { Intramuscular } \\
\mathrm{NK} \\
\mathrm{NK} \\
\mathrm{NK} \\
\text { Intravenous } \\
\text {," } \\
, \\
, \\
, \\
\text { NK } \\
\mathrm{NK} \\
\mathrm{NK} \\
\mathrm{NK} \\
\text { Intravenous } \\
\text { NK } \\
\mathrm{NK} \\
\mathrm{NK} \\
\mathrm{NK} \\
\mathrm{NK}\end{array}$ & $\begin{array}{l}0 \\
\text { NS } \\
1 \cdot 3 \\
0 \\
0 \\
2 \cdot 4 \\
0 \\
0 \\
0 \cdot 5 \\
1 \cdot 0 \\
2 \cdot 0 \\
0 \\
10 \cdot 0 \\
\mathrm{NS} \\
7 \cdot 0 \\
0 \cdot 2 \\
\mathrm{NS} \\
10 \cdot 0 \\
2 \cdot 2 \\
1 \cdot 3 \\
13 \cdot 0 \\
0 \\
7 \cdot 1 \\
\mathrm{NS} \\
0 \cdot 8 \\
0 \\
10 \cdot 0 \\
2 \cdot 5 \\
2 \cdot 5\end{array}$ & $\begin{array}{c}0 \cdot 7 \\
1 \cdot 0 \\
1 \cdot 0 \\
2 \cdot 5 \\
0 \cdot 5 \\
10 \cdot 0^{*} \\
4 \cdot 0 \\
2 \cdot 0 \\
0 \cdot 5 \\
0 \cdot 5 \\
0 \\
1 \cdot 0 \\
7 \cdot 0^{+} \\
5 \cdot 0^{+} \\
6 \cdot 0^{+} \\
\mathrm{NS} \\
1 \cdot 0 \\
\mathrm{NS} \\
0 \\
0 \\
7 \cdot 0 \\
1 \cdot 0 \\
1 \cdot 9 \\
11 \cdot 0^{+} \\
0 \\
1 \cdot 0 \\
10 \cdot 0 \\
1 \cdot 0^{*} \\
2 \cdot 0\end{array}$ \\
\hline
\end{tabular}

* Subdural empyema. +Bloodstained specimen. NK = Not known. NS = No specimen. 
In pus many of the higher concentrations were found in heavily blood-stained specimens. Four patients with detectable concentrations in pus of $1.0 \mathrm{mg} / 1$ or less were also infected with 3 -lactamase-producing bacteria.

Sixteen patients were treated with other $\beta$-lactam antibiotics. Positive results were obtained from 13 (table II). One patient receiving ampicillin and two receiving cloxacillin had negative assays in both pus and serum. Three of the patients treated with ampicillin were infected with $\beta$-lactamase-producing Staphylococcus aureus. Clearly, none of these agents penetrated well into intracranial pus, and only in heavily blood-stained samples did the concentrations of active agent in the pus exceed $1.5 \mathrm{mg} /$.

Assay results on other agents used to treat these patients are sliown in table III. The five patients treated with gentamicin had low concentrations in the samples assayed. In addition to these five, two others received kanamycin or streptomycin. In both cases the assays were negative. Six patients received chloramphenicol. Unless ad-

TABLE II-Concentrations of other -lactam antibiotics in serum and intracranial pus in ten patients

\begin{tabular}{|c|c|c|c|c|}
\hline Drug & $\begin{array}{c}\text { Dose } \\
\text { (g day) }\end{array}$ & Route & $\begin{array}{l}\text { Serum } \\
(\mathrm{mg} \mathrm{l})\end{array}$ & $\underset{(\mathrm{mg} \mathrm{l})}{\text { Pus }}$ \\
\hline Ampicillin & $\begin{array}{r}4 \cdot 0 \\
\mathrm{~N} K \\
2 \cdot 0 \\
2 \cdot 0 \\
2 \cdot 0\end{array}$ & $\begin{array}{l}\text { Oral } \\
\text { Oral } \\
\text { Oral } \\
\text { Oral }\end{array}$ & $\begin{array}{r}6.0 \\
10.0 \\
0.5 \\
2.5 \\
2.5\end{array}$ & $\begin{array}{l}3.5^{*} \\
0.5 \\
0.5 \\
1.1 \\
1.0\end{array}$ \\
\hline Cloxacillin & $\begin{array}{r}4 \cdot 0 \\
4 \cdot 0 \\
\text { NK } \\
2 \cdot 0 \\
6 \cdot 0\end{array}$ & $\begin{array}{c}\text { Intravenous } \\
, \\
\text { Intravenous } \\
,,\end{array}$ & $\begin{array}{r}2 \cdot 0 \\
2 \cdot 7 \\
10 \cdot 0 \\
2 \cdot 0 \\
7 \cdot 5\end{array}$ & $\begin{array}{l}2 \cdot 0^{*} \\
0.5 \\
0.5 \\
2.0^{*} \\
0.5\end{array}$ \\
\hline Cephaloridine & $\begin{array}{r}2 \cdot 0 \\
0 \cdot 8 \\
0 \cdot 8 \\
0.8 \\
N K \\
4 \cdot 0 \\
4 \cdot 0\end{array}$ & $\begin{array}{c}\text { Intramuscular } \\
, " \\
\text { Intramuscular } \\
, "\end{array}$ & $\begin{array}{l}1.5 \\
0 \\
\text { NS } \\
1.5 \\
N S \\
5 \cdot 0 \\
1.0\end{array}$ & $\begin{array}{l}1.5 \\
0.1 \\
1.0 \\
0.7 \\
1.0 \\
4.0^{*} \\
\mathrm{NS}\end{array}$ \\
\hline
\end{tabular}

*Heavily bloodstained. NS = No specimen. $\mathrm{NK}=$ Not known.

TABLE III-Concentrations of non-3-lactam antibiotics in serum and intracranial pus in nine patients

\begin{tabular}{|c|c|c|c|c|}
\hline Drug & Daily dose & Route & $\begin{array}{l}\text { Serum } \\
(\mathrm{mg} 1)\end{array}$ & $\underset{(\mathrm{mg} \mathrm{l})}{\text { Pus }}$ \\
\hline Gentamicin & $\begin{array}{l}160 \mathrm{mg} \\
240 \mathrm{mg} \\
240 \mathrm{mg} \\
240 \mathrm{mg} \\
\mathrm{NK}\end{array}$ & $\begin{array}{c}\text { Intramuscular } \\
\text {," } \\
, " \\
,\end{array}$ & $\begin{array}{l}1 \cdot 5 \\
1 \cdot 0 \\
1 \cdot 0 \\
0 \cdot 3 \\
4 \cdot 5\end{array}$ & $\begin{array}{r}0.5 \\
<0.5 \\
1.0 \\
0 \\
<0.5\end{array}$ \\
\hline Chloramphenicol & $\begin{array}{l}2.4 \mathrm{~g} \\
2.4 \mathrm{~g} \\
0.12 \mathrm{~g} \\
7 \cdot 2 \mathrm{~g}\end{array}$ & $\begin{array}{c}\text { Intravenous } \\
\text { Local } \\
\text { Intramuscular }\end{array}$ & $\begin{array}{c}13 \cdot 0 \\
0 \\
\text { NS } \\
>10 \cdot 0\end{array}$ & $\begin{array}{c}<5 \cdot 0 \\
0 \\
6 \cdot 0 \\
10 \cdot 0\end{array}$ \\
\hline Fusidic acid & $\begin{array}{l}1.5 \mathrm{~g} \\
\mathrm{NK}\end{array}$ & $\begin{array}{l}\mathrm{NK} \\
\mathrm{NK}\end{array}$ & $\begin{array}{l}6 \cdot 2 \\
\text { NS }\end{array}$ & $\begin{array}{r}6 \cdot 2 \\
>10 \cdot 0\end{array}$ \\
\hline Lincomycin & NK & NK & $8 \cdot 0$ & $4 \cdot 0$ \\
\hline
\end{tabular}

$\mathrm{NK}=$ Not known. $\quad \mathrm{NS}=$ No specimen.

TABLE IV-Levels of antimicrobial drugs in serum and intracranial pus after timed injections in four patients

\begin{tabular}{|c|c|c|c|c|c|}
\hline Drug & Dose & Route & $\begin{array}{l}\text { Time (h) } \\
\text { since last } \\
\text { injection }\end{array}$ & $\begin{array}{l}\text { Serum } \\
(\mathrm{mg} \mathrm{l})\end{array}$ & $\underset{(\mathrm{mg} / \mathrm{l})}{\text { Pus }}$ \\
\hline Penicillin & $\begin{array}{l}4 \mathrm{MU} \\
4 \mathrm{MU} \\
3 \mathrm{MU} \\
3 \mathrm{MU} \\
3 \mathrm{MU}\end{array}$ & Intravenous & $\begin{array}{l}2 \\
2 ! \\
5 \\
5 \\
5\end{array}$ & $\begin{array}{r}7 \cdot 1 \\
2 \cdot 4 \\
10 \cdot 0 \\
\text { NS } \\
7 \cdot 0\end{array}$ & $\begin{array}{c}1.9 \\
10 \cdot 0 \\
7 \cdot 0^{*} \\
5 \cdot 0^{*} \\
6.0^{*}\end{array}$ \\
\hline Cephaloridine & $\begin{array}{l}1.0 \mathrm{~g} \\
1.0 \mathrm{~g}\end{array}$ & & $\begin{array}{l}5 \\
5\end{array}$ & $\begin{array}{l}1.5 \\
\text { NS }\end{array}$ & $\begin{array}{l}0.7 \\
1 \cdot 0\end{array}$ \\
\hline Chloramphenicol & $1 \cdot 2 \mathrm{~g}$ & & 1 & $>10 \cdot 0$ & $>10 \cdot 0^{*}$ \\
\hline
\end{tabular}

*Heavily bloodstained. NS $=$ No specimen. ministered locally the pus levels of active agent were low except when the sample was bloodstained. Fusidic acid and lincomycin seemed to penetrate well. Assays carried out on samples from six patients who received sulphonamides or co-trimoxazole gave unreliable results.

Samples from four patients were collected at timed intervals after injection of penicillin, chloramphenicol, or cephaloridine (table IV). The results suggested that adequate concentrations of antibiotic would be maintained in the abscess cavity if such doses were repeated every four to six hours.

\section{Discussion}

The results of this study show that there is wide variation in the concentration of penicillin demonstrable in intracranial pus and that to some extent this is independent of the dose administered, although regimens of 4 megaunits per day or less failed to produce adequate concentrations within the abscess cavity as judged by clinical response. Serum penicillin concentrations may be of value in monitoring treatment, since in most patients on continuous treatment who had serum concentrations greater than $1 \mathrm{mg} / \mathrm{l}$ the drug was detectable in the pus sample. In addition to patient variation, the production of $\beta$-lactamase by the infecting organism, and the effects of contamination by blood, the ability of some samples of pus to inactivate penicillin" rapidly must also be considered. In the only published study on antibiotic penetration into brain abscess cavities" it was reported that, in three patients, penicillin could penetrate in therapeutic concentrations. Kramer $e^{2} a^{4}$ reported that the concentration of penicillin in uninflamed brain tissue was $5^{\prime \prime}{ }^{\prime}$ of the blood concentration. This is lower than the concentration shown in this study, which suggests that, as is the case with penetration into $\mathrm{CSF},{ }^{10}$ the passage of penicillin, and also of ampicillin, is enhanced by local inflammation.

Our finding that cephaloridine penetrated poorly agrees with those of Kramer et $a l^{4}$ and suggests that further work needs to be carried out to determine the value of the cephalosporins in treating brain abscess. Cloxacillin also penetrates poorly.

Chloramphenicol is widely used in the treatment of CNS infections, but our results and those of Black et al suggest that penetration, though sometimes good, is erratic. In contrast, it has been reported that chloramphenicol is concentrated ninefold in brain tissue. ${ }^{4}$ This divergence of opinion has yet to be resolved. The aminoglycosides penetrate poorly into abscess cavities, while in the cases studied the penetration of fusidic acid and lincomycin was good. The results of this study and of subsequent clinical experience suggest that fusidic acid is more suitable than cloxacillin in the treatment of staphylococcal infection.

Metronidazole was not used in the treatment of these patients. Recent reports ${ }^{11-14}$ suggest that it is highly active in anaerobic infections of the CNS, although the extent to which it penetrates intracranial pus and brain tissue has yet to be established. Such studies are highly desirable.

The failure of antibiotics to eradicate localised infection within the CNS has been attributed to the inadequate or inappropriate use of antibiotics, ${ }^{15}$ to the protection afforded to micro-organisms by the purulent milieu," and to the presence of bacterial enzymes or tissue products capable of degrading penicillin. ${ }^{9}$ Garfield $^{15}$ recommended penicillin as the drug of choice for treating brain abscess. The high incidence of infection with penicillin-resistant bacteria $^{6}$ suggests that alternative therapeutic regimens need to be established. The results of our studies $^{6-9}$ indicate that the treatment of abscesses of the central nervous system should be considered in four categories.

Abscesses of sinusitic origin-These are most often due to metronidazole-resistant streptococci, which are highly sensitive to penicillin. Mixed infections are unusual and therefore penicillin (16-24 megaunits/day) is the treatment of first choice.

Abscesses of otitic origin-These are due to a wide range of aerobic and anaerobic bacteria, which are often present in mixed cultures. In such cases multiple antibiotic treatment should be 
used-for example, chloramphenicol and metronidazole with or without the addition of penicillin, ampicillin, or co-trimoxazole.

Abscesses of metastatic or cryptogenic origin-These may be streptococcal, or may be caused by a mixture of bacteria. Multiple treatment should be used until bacteriological results are available, after which it may be possible to continue treatment with a single drug.

Spinal and post-traumatic intracranial abscesses-These are usually caused by Staph aureus. Our findings, supported by subsequent clinical experience, suggest that in such cases fusidic acid is the drug of first choice.

Our studies on the penetration of chemotherapeutic agents into intracranial lesions, their activity within such sites, and the clinical effects which they produce are continuing.

The reurosurgical centres participating in the study were: Atkinson Morley's Hospital, London; Frenchay Hospital, Bristol; Regional Centre for Neurosurgery, Romford; St Bartholomew's Hospital, London; Walton Hospital, Liverpool; Wessex Neurological Centre, Southampton. The examining laboratory was Queen Charlotte's Maternity Hospital, London.

This study formed part of a thesis submitted for the degree Doctor of Philosophy in the Faculty of Medicine, University of London.

\section{References}

'Davson, H, and Smith, H V, Proceedings of the Royal Society of Medicine, 1957, 50, 963.

'Garrod, L P, Lambert, H P, and O'Grady, F, Antibiotic and Chemotherapy, p 349. London, Churchill Livingstone, 1973.

Wellman, W E, et al, fournal of Laboratory and Clinical Medicine, 1954 43, 275 .

'Kramer, P W, Griffith, R S, and Campbell, R L, fournal of Neurosurgery, 1969, 31, 295

'Black, P, Graybill, J R, and Charache, P, Journal of Neurosurgery, 1973, 38, 705 .

"de Louvois, J, Gortvai, P, and Hurley, R, British Medical fournal, 1977, 2,981

' de Louvois, J, Thesis for the degree Doctor of Philosophy, University of London, 1977.

de Louvois, J, and Hurley, R, Chemotherapy Progress, 1975, 4, 61

${ }^{9}$ de Louvois, J, and Hurley, R, British Medical fournal, 1977, 1, 998.

"Lithander, A, and Lithander, B, Acta Pathologica et Microbiologica Scandinavica, 1962, 56, 435.

Ingham, H R, et al, Antimicrobial Chemotherapy, 1975, 1, 235.

1.2 Ingham, H R, et al, British Medical fournal, 1975, 4, 39.

${ }^{13}$ George, R H, and Bint, A J, Antimicrobial Chemotherapy, 1976, 2, 100.

"Ingham, H R, Selkon, J B, and Roxby, C M, Antimicrobial Chemotherapy. In press.

${ }^{15}$ Garfield, J, British Medical fournal, 1969, 2, 7

(Accepted 12 September 1977)

\title{
Effect of preoperative anaesthetic visit on anxiety
}

\author{
JULIAN M LEIGH, J WALKER, P JANAGANATHAN
}

British Medical fournal, 1977, 2, 987-989

\section{Summary}

Anxiety levels measured in patients who received preoperative reassurance about anaesthesia from a member of the hospital staff were significantly lower than those in a control group given no such support. Anxiety levels in patients who read a booklet designed to reassure about anaesthesia were less significantly reduced. Owing to the increasing work load in the operating theatre many anaesthetists can no longer afford the time to visit patients preoperatively. This study shows that either this trend should be reversed or the role of reassurer should be assumed by someone else, possibly the anaesthetic nurse. For optimal effect, the visits should be combined with use of the booklet. Unless such measures are taken, up to three million people each year may be being denied any form of reassurance before surgical treatment.

\section{Introduction}

Patients admitted to hospital for surgery naturally experience anxiety, and it has long been generally assumed that a preoperative visit by the anaesthetist reduces apprehension, parti-

St Luke's Hospital, Guildford, Surrey GU1 3NT

JULIAN M LEIGH, MD, FFARCS, consultant anaesthetist

P JANAGANATHAN, FFARCS, senior registrar

University of Surrey, Guildford

J WALKER, MSC, psychologist cularly concerning the outcome of anaesthesia. In our experience, however, with the increasing work load in the operating theatre, anaesthetists are finding less time to undertake such visits. Although medical problems may be dealt with by the surgical houseman, the absence of the anaesthetist's visit may be depriving the patient of a means of reducing preoperative anxiety.

The object of this study was to determine whether the preoperative visit by the anaesthetist was of any value in alleviating anxiety, since its effect had not previously been measured quantitatively. We also hoped to discover whether a specially written booklet, About Your Anaesthetic, might be successfully substituted for these visits, or whether neither of these procedures had any effect on the patient's anxiety.

The comparative effects of a visit by an anaesthetist or a dose of pentobarbitone or both were investigated by Egbert et al, ${ }^{1}$ and the sources of preoperative anxiety were studied by Norris and Baird. ${ }^{2}$ Anxiety may be difficult to estimate ${ }^{3}$ and the patients in those studies were assessed qualitatively as "anxious" or "non-anxious" on a subjective or objective basis. Ramsay, in a study of preoperative fear, used a similar objective-subjective impression approach to determine whether anxiety or fear were present or absent. Simple evaluations of this type rely on personal judgment, however, and do not permit fine discrimination, particularly of mild to moderate grades of anxiety. The Spielberger self-evaluation questionnaire ${ }^{5}$ remedies this and not only enables the patient to estimate the grade of his anxiety level himself but also enables underlying "trait anxiety" (part 1 of the questionnaire) to be distinguished from immediate "state anxiety" (part 2).

Trait anxiety is defined as a basic personality feature. It describes how a person generally feels, and is assumed to be reasonably constant for a given patient. State anxiety is the anxiety level at any particular moment and depends on the environmental factors operating at that time. Spielberger and his colleagues developed this concept of state-trait anxiety 